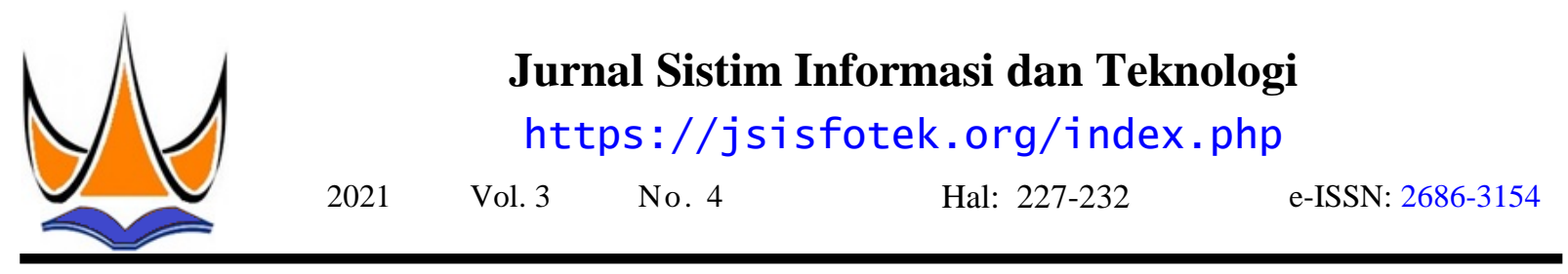

\title{
Sistem Pakar dalam Menganalisis Gangguan Jiwa Menggunakan Metode Certainty Factor
}

\author{
Rafi Septiawan Putra ${ }^{1 凶}$, Yuhandri Yunus ${ }^{2}$ \\ ${ }^{1,2}$ Univesitas Putra Indonesia YPTK Padang \\ rafi.putra95@gmai1.com
}

\begin{abstract}
People with Mental Disorders (ODGJ) as a trigger for people who suffer from disorders of thought, feeling and behavior cause changes in attitudes and behavior that hinder normal human functioning. Mental disorders as a syndrome characterized by a change in a person's behavior that will be associated with symptoms such as difficulties or disorders, as well as psychological functions and behavior that are not confident in dealing with people but can also be with that person. An expert system is an intelligent computer technology that is based on solving problems using inferential knowledge and procedures. As a problem solver, expert systems will also find it easier to make decisions or policies like humans do. This study aims to produce an expert system that is used to analyze mental disorders who can make similar decisions, as well as psychiatric specialists. The data processed in this study is scientific data on mental disorders ranging from types of mental illness, early symptoms of disease and patient diagnosis data by mental health specialists, then the data is processed using the Certainty Factor method and displayed in the form of a web-based application using the PHP programming language. and MySQL databases. The results obtained from testing the expert system using the Certainty Factor method show that there is a match between the results of an expert diagnosis of depression with a certainty level of $73 \%$. An expert system for analyzing mental disorders using the Certainty Factor method can make it easier for sufferers to understand the type of mental disorder they are experiencing.
\end{abstract}

Keywords: Expert System, Mental Disorders, Certainty Factor, PHP, Database MySQL.

\begin{abstract}
Abstrak
Orang Dengan Gangguan Jiwa (ODGJ) didefinisikan sebagai seseorang yang menderita gangguan pikiran, perilaku dan perasaan sehingga terjadinya perubahan sikap dan perilaku yang menghambat fungsi sebagai manusia normal. Gangguan jiwa merupakan sebuah sindrom yang di tandai dengan perubahan perilaku seseorang selalu berkaitan dengan gejala seperti penderitaan (distress) atau hendaya (impairment), selain itu fungsi psikologik dan perilaku tidak selalu terletak dalam hubungan antara orang tersebut melainkan bisa dengan masyarakat. Sistem pakar merupakan teknologi komputer pintar yang berasaskan pada problem solver dengan pemanfaatan pengetahuan dan prosedur inferensi. Sebagai problem solver, sistem pakar juga akan memudahkan dalam penentuan keputusan atau kebijakan seperti yang dilakukan manusia. Penelitian ini bertujuan untuk menghasilkan sistem pakar yang digunakan untuk menganalisis gangguan jiwa yang mampu membuat suatu keputusan yang sama, sebaik layaknya seorang dokter spesialis kedokteran jiwa. Data yang diolah dalam penelitian ini adalah data keilmuan tentang gangguan kejiwaan mulai dari jenis penyakit jiwa, gejala awal penyakit serta data diagnosa pasien oleh dokter spesialis kedokteran jiwa, selanjutnya data diolah menggunakan metode Certainty Factor dan di disajikan dalam bentuk aplikasi berbasis web menggunakan Bahasa pemograman PHP dan basisdata MySQL. Hasil yang didapatkan dari pengujian sistem pakar dengan menggunakan metode $\mathrm{s}$ menunjukkan bahwa terdapat kesesuaian antara hasil diagnosa pakar pada gangguan depresi dengan tingkat kepastian 73\%. Sistem pakar dalam menaganalisis gangguan jiwa menggunakan metode Certainty Factor ini dapat memudahkan penderitanya mengetahui jenis gangguan jiwa yang dialami.
\end{abstract}

Kata kunci: Sistem Pakar, Gangguan Jiwa, Certainty Factor, PHP, Basisdata MySQL.

(C) 2021 JSisfotek

\section{Pendahuluan}

Teknologi kecerdasan buatan menjadi salah satu keunggulan baru dari ilmu komputer yang menjadikan sebuah sistem bekerja seperti apa yang dilakukan oleh otak manusia [1]. Ahli Teknologi Sistem Pakar sekaligus guru besar dari Universitas Standford Profesor Edward Feigenbaum menjelaskan sistem pakar merupakan teknologi komputer pintar yang berasaskan pada problem solver dengan pemanfaatan pengetahuan dan prosedur inferensi [2]. Sistem pakar juga merupakan suatu sistem yang menjadikan pengetahuan dari manusia kemudian di ubah kedalam komputer sehingga komputer mampu menyelesaikan persoalan seperti yang dilakukan oleh para pakar [3]. Sistem ini dapat membantu orang awam dalam menyelesaikan permaslaahan yang rumit yang hanya dapat diselesaikan dengan bantuan para pakar [4]. Pada dasarnya system berbasis computer memanfaatkan informasi, fakta dan teknik penalaran untuk seorang ahli dalam menyelesaikan persoalan [5]. Orang Dengan Gangguan Jiwa (ODGJ) didefinisikan sebagai seseorang yang menderita gangguan pikiran, perilaku dan perasaan sehingga terjadinya perubahan sikap dan perilaku yang menghambat fungsi sebagai manusia normal [6]. Gangguan jiwa atau psikis disebabkan oleh faktor yang multi-kausal. Faktor-faktor berasal dari 
orang itu sendiri, terutama pada psikis sseorang dan diolah dalam penelitian ini adalah data keilmuan pengaruh sosial dimana mempengaruhi antara satu tentang gangguan kejiwaan mulai dari jenis penyakit dengan yang lainnya [7]. Maka dilakukan penelitian jiwa, gejala awal penyakit serta data diagnosa pasien dengan menggunakan metode Certainty Factor (CF). oleh dokter spesialis kedokteran jiwa yang diperoleh Certainty Factor (CF) adalah suatu nilai yang pada saat wawancara.

digunakan untuk mengukur keyakinan pakar [8].

Shortliffe Buchanan merupakan orang yang memperkenalkan Certainty Factor (CF) dalam Data yang diolah dalam penelitian ini merupakan data pembuatan sistem pakar MYCIN untuk menunjukkan gejala gangguan jiwa yang terdiri dari beberapa jenis besarnya nilai kepercayaan [9]. Metode Certainty gangguan jiwa. Berikut daftar 4 jenis gangguan jiwa Factor memiliki kelebihan yaitu metode ini sangat yang dapat dilihat pada Tabel 1 sampai dengan Tabel 7. cocok digunakan untuk sistem pakar karena keakuratan data yang diolah dapat terjaga karena dalam sekali proses perhitungan keakuratan hanya dapat mengolah dua data saja [10]. Metode Certainty Faktor (Faktor Kepastian) dapat menjadi jawaban keyakinan kepada pakar atas ketidakpastian dalam menerjemahkan informasi atau pengetahuan melalui analisis yang membentuk sebuah matrik [11]. Dengan adanya system pakar menggunakan metode Certainty Factor ini, maka pakar dan pasien maupun masyarakat umum bisa dengan mudah mengetahui jenis gangguan jiwa yang diderita oleh penyandang gangguan jiwa [12].

\section{Metodologi Penelitian}

Penelitian ini merupakan sitem pakar dalam menganalisis gangguan jiwa. Penelitian ini dirinci dalam tahapan-tahapan yang disajikan dalam bentuk alur dengan urutan Langkah-langkahnya seperti yang disajikan pada Gambar 1.

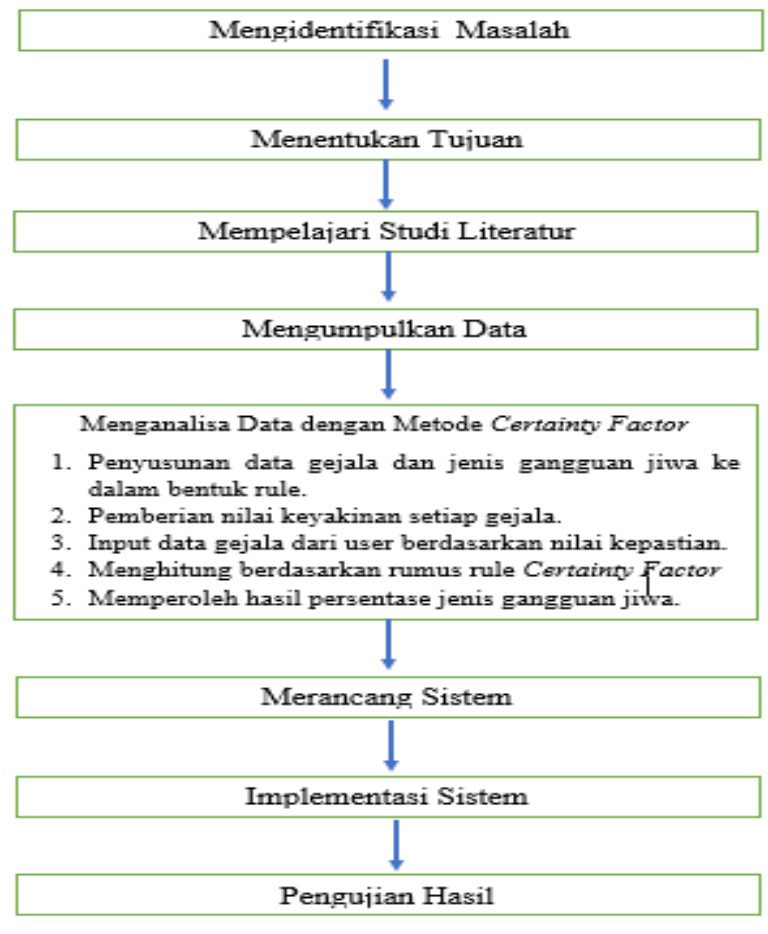

Gambar 1. Kerangka Kerja Penelitian
Tabel 1. Gejala Gangguan Depresi

\begin{tabular}{ll}
\hline Nama Penyakit & \multicolumn{2}{l}{ Gejala } \\
\hline & 1. Perubahan Nafsu Makan \\
& 2. Sulit Tidur \\
& 3. Bicara dan bergerak lebih lambat \\
Gangguan Depresi & 4. Kehilangan kepercayaan diri \\
& 5. Merasa bersalah pada diri sendiri \\
& 6. Berniat menyakiti diri sendiri / bunuh diri \\
& 7. Sulit Konsentrasi \\
& 8. Sering Merasa Sedih
\end{tabular}

Tabel 2. Gejala Gangguan Kecemasan

\begin{tabular}{ll}
\hline Nama Penyakit & Gejala \\
\hline & 1. Dada berdebar \\
& 2. Sulit tidur \\
& 3. Berkeringat, dan bergetar. \\
& 4. Sulit bernafas \\
Gangguan Kecemasan & 5. Merasa tercekik \\
& 6. Nyeri dan sesak di dada \\
& 7. Mual dan gangguan perut \\
& 8. Pusing atau sakit kepala \\
& 9. Rasa takut dan kwatir berlebih \\
\hline
\end{tabular}

Tabel 3. Gejala Skizofrenia

\begin{tabular}{|c|c|}
\hline $\begin{array}{c}\text { Nama } \\
\text { Penyakit }\end{array}$ & Gejala \\
\hline Skizofrenia & $\begin{array}{l}\text { 1. Mudah tersinggung } \\
\text { 2. Sulit konsentrasi } \\
\text { 3. Sulit tidur. } \\
\text { 4. Mendengar atau melihat hal-hal yang tidak ada } \\
\text { 5. Kulusinasi). } \\
\text { 6. Yakin terhadap sesuatu yang tidak nyata } \\
\text { 7. } \quad \text { Berbicara yang tidak masuk akal. } \\
\end{array}$ \\
\hline \multicolumn{2}{|r|}{ Tabel 4. Gejala Gangguan Bipolar } \\
\hline Nama Penyakit & Gejala \\
\hline $\begin{array}{l}\text { Gangguan } \\
\text { Bipolar }\end{array}$ & $\begin{array}{ll}\text { 1. } & \text { Sulit tidur } \\
\text { 2. } & \text { Terlalu percaya diri } \\
\text { 3. } & \text { Berbicara lebih cepat } \\
\text { 4. } & \text { Sulit berkonsentrasi } \\
\text { 5. } & \text { Mudah tersinggung } \\
\text { 6. } & \text { Sering Merasa Sedih } \\
\text { 7. } & \text { Bicara dan bergerak lebih lambat } \\
\text { 8. } & \text { Sulit tidur } \\
\text { 9. } & \text { Rasa takut dan kwatir berlebih } \\
\text { 10. } & \text { Berniat menyakiti diri sendiri / bunuh diri }\end{array}$ \\
\hline
\end{tabular}

Berdasarkan jenis gangguan jiwa diatas dari hasil pengumpulan data dari wawancara dengan pakar maka ditarik kesimpulan terdapat gejala-gejala gangguan jiwa, dimana setiap jenis gangguan diberikan kode huruf dan angka seperti pada Tabel 5.

Penelitian ini memiliki tujuan untuk membangun sebuah sistem pakar dalam menganalisis gangguan jiwa menggunakan metode Certainty Factor. Data yang 
Tabel 5. Gejala Gangguan Jiwa

\begin{tabular}{cl}
\hline Kode Gejala & Nama Gejala \\
\hline G01 & Perubahan Nafsu Makan \\
G02 & Gangguan Tidur \\
G03 & Bicara/Bergerak Lebih Lambat \\
G04 & Kehilangan Kepercayaan Diri \\
G05 & Merasa bersalah pada diri sendiri \\
G06 & Berniat menyakiti diri sendiri / bunuh diri \\
G07 & Sering Merasa Sedih \\
G08 & Dada berdebar \\
G09 & Sulit bernafas \\
G10 & Merasa tercekik \\
G11 & Nyeri dan sesak di dada \\
G12 & Mual dan gangguan perut \\
G13 & Pusing atau sakit kepala \\
G14 & Rasa takut dan khawatir berlebih \\
G15 & Mudah tersinggung/curiga \\
G16 & Sulit konsentrasi \\
G17 & Mendengar atau melihat yang tidak ada (halusinasi) \\
G18 & Kurang bersosialisasi \\
G19 & Yakin terhadap sesuatu yang tidak nyata (Delusi) \\
G20 & Bicara yang tidak masuk akal \\
G21 & Terlalu percaya diri \\
G22 & Bicara cepat dan berganti-ganti topik \\
G23 & Gelisah dan mudah marah \\
G24 & Penurunan kemampuan berperilaku \\
G25 & Diam membisu/ekpresi datar \\
G26 & Senang berlebih \\
\hline &
\end{tabular}

Dimana $G$ merupakan kode huruf untuk gejala dan angka merupakan urutan nomor berdasarkan gejalagejala yang dialami oleh penyandang gangguan jiwa. Berdasarkan data yang telah dikumpulkan dari pakar diperoleh 4 jenis gangguan jiwa. Jenis ganggguan jiwa diberikan kode huruf huruf dan angka seperti pada Tabel 6.

Tabel 6. Jenis Gangguan Jiwa

\begin{tabular}{cl}
\hline Kode Penyakit & Nama Penyakit \\
\hline P01 & Gangguan Depresi \\
P02 & Gangguan Kecemasan Menyeluruh \\
P03 & Skizofrenia \\
P04 & Gangguan Bipolar \\
\hline
\end{tabular}
Dimana P merupakan kode huruf untuk jenis gangguan $\quad(\mathrm{FK}=0.8)$ AND G06 (FK=0.6) AND G07 FK=1.0) jiwa dan angka merupakan urutan nomor berdasarkan $(\mathrm{FK}=1.0)$ THEN P01 (FK=0.79)

jenis ganggguan jiwa. Metode yang digunakan untuk FK1 (G01, G02, G03, G04, G05, G06, G07, G15, G16, mendapatkan tingkat keyakinan Certainty Factor dari G18 @ P02)

sebuah rule yang digunakan yaitu mewawancarai $=\operatorname{Min}[1.0 ; 1.0 ; 0,7 ; 0,8 ; 0,8 ; 0,6 ; 1,0 ; 0,7 ; 0,7 ; 1,0] *$ seorang dokter spesialis kedokteran jiwa, Nilai rule 0.79

pada Certainty Factor diperoleh dari interpretasi $=0,6 * 0,79$

"term" dari dokter spesialis kedokteran jiwa yang $=0,47$

dijadikan kedalam bentuk nilai Certainty Factor seperti

Tabel 7.

Tabel 7. Nilai Certainty Factor

\begin{tabular}{lc}
\hline \multicolumn{1}{c}{ Uncertain Term } & Nilai FK \\
\hline Tidak Pasti & 0,0 \\
Hampir Tidak Pasti & 0.2 \\
Kemungkinan Besar Tidak & 0.3 \\
Mungkin Tidak & 0.4 \\
Kemungkinan Kecil & 0.5 \\
Mungkin & 0.6 \\
Kemungkinan Besar & 0.7 \\
Hampir Pasti & 0.8 \\
Pasti & 1 \\
\hline
\end{tabular}

Rule 3 : Tidak dapat dieksekusi karena ada evidence yang tidak fakta.

Selanjutnya iterasi yang dilakukan pada rule gangouan jiwa maka diperoleh menganalisis gangguan jiwa yang dialami seperti pada Tabel 8.

Tabel 8. Nilai Rule

\begin{tabular}{lc}
\multicolumn{1}{c}{ Rule } & Nilai FK \\
\hline R1 = IF G01 AND G02 AND G03 AND G04 AND & 0.81 \\
G05 AND G06 AND G07 AND G16 THEN P01 & \\
R2 = IF G01 AND G02 AND G03 AND G04 AND & \\
G05 AND G06 AND G07 AND G15 AND G16 & 0.79 \\
AND G18 THEN P01 & \\
R3 = IF G02 AND G08 AND G09 AND G10 AND & 0.85 \\
G11 AND G12 AND G13 AND G14 THEN P02 & \\
R4 = IF G02 AND G17 AND G18 AND G19 AND & 0.93 \\
G20 AND G23 AND G24 AND G26 THEN P03 & \\
R5 = IF G03 AND G16 AND G18 AND G20 AND & 0.90 \\
G24 AND G25 THEN P03 & \\
R6 = IF G03 AND G17 AND G19 AND G20 AND & 0.96 \\
G24 THEN P03 & \\
R7 = IF G03 AND G18 AND G20 AND G24 AND & 0.92 \\
G25 THEN P03 & \\
R8 = IF G02 AND G05 AND G07 AND G15 AND & \\
G16 AND G18 AND G20 AND G21 AND G23 & 0.78 \\
AND G26 THEN P04 \\
R9 = IF G02 AND G05 AND G07 AND G15 AND \\
G16 AND G24 AND G26 THEN P04
\end{tabular}

Keterangan dari setiap rule dari fakta baru adalah:

1: IF G01 (FK=1.0) AND G02 (FK=1.0) AND $(\mathrm{FK}=0.8)$ AND G06 (FK=0.6) AND G07 $\mathrm{FK}=1.0)$

AND G16 (FK=0.8) THEN P01 (FK=0.81)

(G01, G02, G03, G04, G05, G06, G07, G16へP02)

$=0,6 * 0,81$

$=0,49$

Rule 2 : IF G01 (FK=1.0) AND G02 (FK=1.0) AND G03 $(\mathrm{FK}=0.7) \quad$ AND G04 $(\mathrm{FK}=0.8) \quad$ AND $\mathrm{G} 05$ Rule 4 : Tidak dapat dieksekusi karena ada evidence yang tidak fakta.

Rule 5 : Tidak dapat dieksekusi karena ada evidence yang tidak fakta.

Rule 6 : Tidak dapat dieksekusi karena ada evidence yang tidak fakta.

Rule 7 : Tidak dapat dieksekusi karena ada evidence yang tidak fakta.

Rule 8 : Tidak dapat dieksekusi karena ada evidence yang tidak fakta. 
Rule 9 : Tidak dapat dieksekusi karena ada evidence yang tidak fakta.

Berdasarkan hasil dari fakta baru diperoleh rule 1 dan rule 2, memiliki hipotesa yang sama yaitu P02, oleh karena itu dilakukan proses perhitungan menggunakan FK Gabungan :

FKCombine $\mathrm{FK}(\mathrm{X}, \mathrm{Y})$ old $1=\mathrm{FK}(\mathrm{X}, \mathrm{Y}) \mathrm{r} 1+\mathrm{FK}(\mathrm{X}, \mathrm{Y})$ $\mathrm{r} 2 *[1-\mathrm{FK}(\mathrm{X}, \mathrm{Y}) \mathrm{r} 1]$

$=0,49+(0,47 *[1-0,49])$

$=0,49+(0,47 * 0,51)$

$=0,73$

Berdasarkan hasil perhitungan diperoleh tingkat kepastian pasien 1 dengan diagnosis gangguan depresi dengan nilai sebesar 0.73 atau 73 \%Berdasarkan Rule pada Tabel 8 maka akan dilakukan proses perhitungan Certainty Factor gangguan jiwa pada pasien yang diuji disajikan pada Tabel 9 dan Tabel 10.

Tabel 9. Gejala Pasien 1

\begin{tabular}{|c|c|c|}
\hline Kode & Pertanyaan & Jawaban \\
\hline G01 & $\begin{array}{l}\text { Apakah pasien mengalami perubahan } \\
\text { nafsu makan (meningkat/menurun)? }\end{array}$ & Pasti \\
\hline G02 & $\begin{array}{l}\text { Apakah pasien mengalami gangguan tidur } \\
\text { (sulit tidur atau banyak tidur)? }\end{array}$ & Pasti \\
\hline G03 & $\begin{array}{l}\text { Apakah pasien bicara/bergerak lebih } \\
\text { lambat? }\end{array}$ & $\begin{array}{l}\text { Kemungkinan } \\
\text { Besar }\end{array}$ \\
\hline G04 & $\begin{array}{l}\text { Apakah pasien mengalami kehilangan } \\
\text { kepercayaan diri? }\end{array}$ & Hampir Pasti \\
\hline G05 & $\begin{array}{l}\text { Apakah pasien merasa bersalah pada diri } \\
\text { sendiri? }\end{array}$ & Hampir Pasti \\
\hline G06 & $\begin{array}{l}\text { Apakah pasien berniat menyakiti diri } \\
\text { sendiri / bunuh diri? }\end{array}$ & Mungkin \\
\hline G07 & Apakah pasien sering merasa sedih? & Pasti \\
\hline G08 & Apakah pasien merasakandada berdebar? & Tidak Pasti \\
\hline G09 & Apakah pasien sulit bernafas? & Tidak Pasti \\
\hline G10 & Apakah pasien merasa tercekik? & Tidak Pasti \\
\hline G11 & Apakah pasien nyeri dan sesak di dada? & Tidak Pasti \\
\hline G12 & Apakah pasien mual dan gangguan perut? & Tidak Pasti \\
\hline G13 & Apakah pasien pusing atau sakit kepala? & Tidak Pasti \\
\hline G14 & $\begin{array}{l}\text { Apakah pasien memiliki rasa takut dan } \\
\text { khawatir berlebih? }\end{array}$ & Tidak Pasti \\
\hline G15 & $\begin{array}{l}\text { Apakah pasien mudah tersinggung/curiga } \\
\text { kepada orang lain? }\end{array}$ & $\begin{array}{l}\text { Kemungkinan } \\
\text { Besar }\end{array}$ \\
\hline G16 & $\begin{array}{l}\text { Apakah pasien sulit konsentrasi dalam } \\
\text { melakukan kegiatan? }\end{array}$ & $\begin{array}{l}\text { Kemungkinan } \\
\text { Besar }\end{array}$ \\
\hline G17 & $\begin{array}{l}\text { Apakah pasien mendengar atau melihat } \\
\text { yang tidak ada (halusinasi)? }\end{array}$ & Tidak Pasti \\
\hline G18 & $\begin{array}{l}\text { Apakah pasien kurang bersosialisasi atau } \\
\text { tidak mau berinteraksi dengan orang lain? }\end{array}$ & Pasti \\
\hline G19 & $\begin{array}{l}\text { Apakah Pasien memiliki keyakinan } \\
\text { terhadap sesuatu yang tidak nyata (Delusi) }\end{array}$ & Tidak Pasti \\
\hline G20 & $\begin{array}{l}\text { Apakah Pasien sering membicarakan yang } \\
\text { tidak masuk akal? }\end{array}$ & Tidak Pasti \\
\hline G21 & $\begin{array}{l}\text { Apakah pasien memiliki sikap terlalu } \\
\text { percaya diri? }\end{array}$ & Tidak Pasti \\
\hline $\mathrm{G} 22$ & $\begin{array}{l}\text { Apakah pasien bicara dengan cepat dan } \\
\text { berganti-ganti topik? }\end{array}$ & Tidak Pasti \\
\hline G23 & $\begin{array}{l}\text { Apakah pasien sering gelisah dan mudah } \\
\text { marah? }\end{array}$ & Tidak Pasti \\
\hline G24 & $\begin{array}{l}\text { Apakah pasien mengalami penurunan } \\
\text { kemampuan berperilaku/tidak dapat } \\
\text { beraktivitas? }\end{array}$ & Tidak Pasti \\
\hline $\mathrm{G} 25$ & $\begin{array}{l}\text { Apakah pasien sering diam membisu atau } \\
\text { sering dengan ekpresi datar/kosong? }\end{array}$ & Tidak Pasti \\
\hline G26 & $\begin{array}{l}\text { Apakah pasien sering mengalami senang } \\
\text { berlebih tanpa sebab? }\end{array}$ & Tidak Pasti \\
\hline
\end{tabular}

Tabel 10. Tabel Pasien 2

\begin{tabular}{|c|c|c|}
\hline $\begin{array}{l}\text { Kode } \\
\text { Gejala }\end{array}$ & Pertanyaan & Jawaban \\
\hline G01 & $\begin{array}{l}\text { Apakah pasien mengalami perubahan } \\
\text { nafsu makan (meningkat/menurun)? }\end{array}$ & Tidak Pasti \\
\hline G02 & $\begin{array}{l}\text { Apakah pasien mengalami gangguan tidur } \\
\text { (sulit tidur atau banyak tidur)? }\end{array}$ & Pasti \\
\hline G03 & $\begin{array}{l}\text { Apakah pasien bicara/bergerak lebih } \\
\text { lambat? }\end{array}$ & Tidak Pasti \\
\hline G04 & $\begin{array}{l}\text { Apakah pasien mengalami kehilangan } \\
\text { kepercayaan diri? }\end{array}$ & Tidak Pasti \\
\hline G05 & $\begin{array}{l}\text { Apakah pasien merasa bersalah pada diri } \\
\text { sendiri? }\end{array}$ & Tidak Pasti \\
\hline G06 & $\begin{array}{l}\text { Apakah pasien berniat menyakiti diri } \\
\text { sendiri / bunuh diri? }\end{array}$ & Tidak Pasti \\
\hline G07 & Apakah pasien sering merasa sedih? & Tidak Pasti \\
\hline G08 & Apakah pasien merasakandada berdebar? & Tidak Pasti \\
\hline G09 & Apakah pasien sulit bernafas? & Tidak Pasti \\
\hline G10 & Apakah pasien merasa tercekik? & Tidak Pasti \\
\hline G11 & Apakah pasien nyeri dan sesak di dada? & Tidak Pasti \\
\hline G12 & Apakah pasien mual dan gangguan perut? & Tidak Pasti \\
\hline G13 & Apakah pasien pusing atau sakit kepala? & Tidak Pasti \\
\hline G14 & $\begin{array}{l}\text { Apakah pasien memiliki rasa takut dan } \\
\text { khawatir berlebih? }\end{array}$ & Tidak Pasti \\
\hline G15 & $\begin{array}{l}\text { Apakah pasien mudah tersinggung/curiga } \\
\text { kepada orang lain? }\end{array}$ & Tidak Pasti \\
\hline G16 & $\begin{array}{l}\text { Apakah pasien sulit konsentrasi dalam } \\
\text { melakukan kegiatan? }\end{array}$ & Mungkin \\
\hline G17 & $\begin{array}{l}\text { Apakah pasien mendengar atau melihat } \\
\text { yang tidak ada (halusinasi)? }\end{array}$ & Pasti \\
\hline G18 & $\begin{array}{l}\text { Apakah pasien kurang bersosialisasi atau } \\
\text { tidak mau berinteraksi dengan orang lain? }\end{array}$ & Hampir Pasti \\
\hline G19 & $\begin{array}{l}\text { Apakah Pasien memiliki keyakinan } \\
\text { terhadap sesuatu yang tidak nyata (Delusi) }\end{array}$ & Pasti \\
\hline G20 & $\begin{array}{l}\text { Apakah Pasien sering membicarakan yang } \\
\text { tidak masuk akal? }\end{array}$ & Pasti \\
\hline G21 & $\begin{array}{l}\text { Apakah pasien memiliki sikap terlalu } \\
\text { percaya diri? }\end{array}$ & Tidak Pasti \\
\hline G22 & $\begin{array}{l}\text { Apakah pasien bicara dengan cepat dan } \\
\text { berganti-ganti topik? }\end{array}$ & Tidak Pasti \\
\hline G23 & $\begin{array}{l}\text { Apakah pasien sering gelisah dan mudah } \\
\text { marah? }\end{array}$ & Mungkin \\
\hline $\mathrm{G} 24$ & $\begin{array}{l}\text { Apakah pasien mengalami penurunan } \\
\text { kemampuan berperilaku/tidak dapat } \\
\text { beraktivitas? }\end{array}$ & Hampir Pasti \\
\hline G25 & $\begin{array}{l}\text { Apakah pasien sering diam membisu atau } \\
\text { sering dengan ekpresi datar/kosong? }\end{array}$ & Tidak Pasti \\
\hline G26 & $\begin{array}{l}\text { Apakah pasien sering mengalami senang } \\
\text { berlebih tanpa sebab? }\end{array}$ & Pasti \\
\hline
\end{tabular}

Keterangan dari setiap rule dari fakta baru:

Rule 1 : Tidak dapat dieksekusi karena ada evidence yang tidak fakta.

Rule 2 : Tidak dapat dieksekusi karena ada evidence yang tidak fakta.

Rule 3 : Tidak dapat dieksekusi karena ada evidence yang tidak fakta.

Rule 4 : IF G02 (FK=1.0) AND G17 (FK=1.0) AND G18 (FK=0.8) AND G19 (FK=1.0) AND G20 $(\mathrm{FK}=1.0)$ AND $\mathrm{G} 23 \quad(\mathrm{FK}=0.6)$ AND $\mathrm{G} 24 \quad(\mathrm{FK}=0.8)$ AND G26 FK=1.0) THEN P03 (FK=0.93) FK1 (G02, G17, G18, G19, G20, G23, G24, G26 ^P03) $=\operatorname{Min}[1,0 ; 1,0 ; 0,8 ; 1,0 ; 1,0 ; 0,6 ; 0,8 ; 1,0] * 0.93$ $=0,6 * 0,93$ $=0,56$ 
Rule 5 : Tidak dapat dieksekusi karena ada evidence yang tidak fakta.

Rule 6 : Tidak dapat dieksekusi karena ada evidence yang tidak fakta.

Rule 7 : Tidak dapat dieksekusi karena ada evidence yang tidak fakta.

Rule 8 : Tidak dapat dieksekusi karena ada evidence yang tidak fakta.

Rule 9 : Tidak dapat dieksekusi karena ada evidence yang tidak fakta.

Berdasarkan hasil dari fakta baru diperoleh rule 4, memiliki hipotesa yang sama yaitu P04, oleh karena itu, berdasarkan hasil perhitungan diperoleh tingkat kepastian pasien 2 dengan diagnosis gangguan bipolar dengan nilai sebesar 0.56 atau $56 \%$.

Pengujian dari dua data pasien dilakukan untuk tingkat 4 keakuratan hasil ssstem pakar berbasis web dengan hasil yang diberikan oleh dokter spesialis kodokteran jiwa. Pada pengujian ini yang menjadi hasil pengujian adalah jenis gangguan jiwa yang bersumber dari data pasien gangguan jiwa. Tabel 11 adalah hasil perhitungan dua data pasien gangguan jiwa.

Tabel 11. Hasil perhitungan 2 dat pasien

\begin{tabular}{cclc}
\hline Kode Pasien & Kode Penyakit & Nama Penyakit & Nilai FK \\
\hline Pasien 1 & P001 & Gangguan Depresi & 0,73 \\
Pasien 2 & P002 & Gangguan Kecemasan & 0,56 \\
\hline
\end{tabular}

Penelitian ini didukung dengan pembuatan system pakar dalam menganalisis gangguan jiwa berbasis web dengan Bahasa pemograman PHP dan basisdata MySQL. Berikut tampilan halaman awal pada Gambar 2.

\section{SISTEM PAKAR DALAM MENGANALISIS GANGGUAN JIWA MENGGUNAKAN} METODE CERTAINTY FACTOR

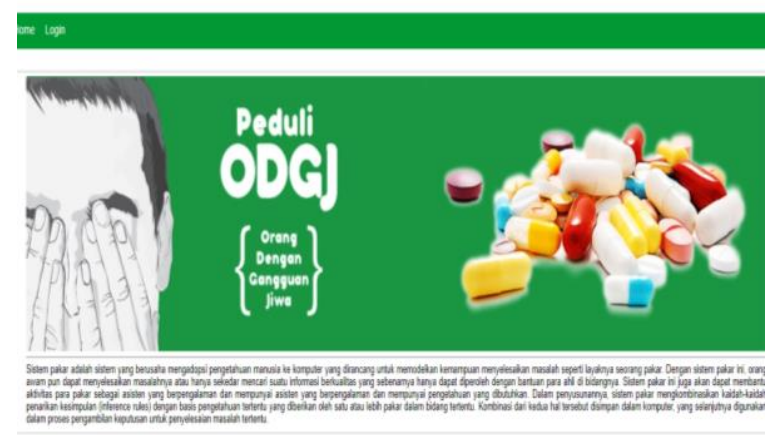

Gambar 2. Tampilan Halaman Awal

Halaman awal menampilkan deskripsi dari system pakar dalam menganalisis gangguan jiwa. Berikut tampilan halaman konsultasi pasien pada sistem pakar dalam menganalisis gangguan jiwa berbasis web pada Gambar 3.
SISTEM PAKAR DALAM MENGANALISIS GANGGUAN JIWA SETIN FACTOR

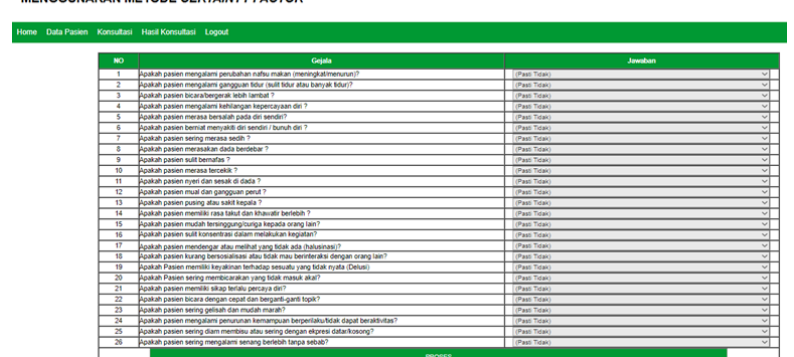

Gambar 3. Tampilan Konsultasi Pasien

Menu konsultasi berisi daftar pertanyaan gejala yang dialami oleh pasien. Berikut tampilan halaman hasil konsultasi pasien pada sistem pakar dalam menganalisis gangguan jiwa berbasis web pada Gambar 4.

SISTEM PAKAR DALAM MENGANALISIS GANGGUAN JIWA

MENGGUNAKAN METODE CERTAINTY FACTOR

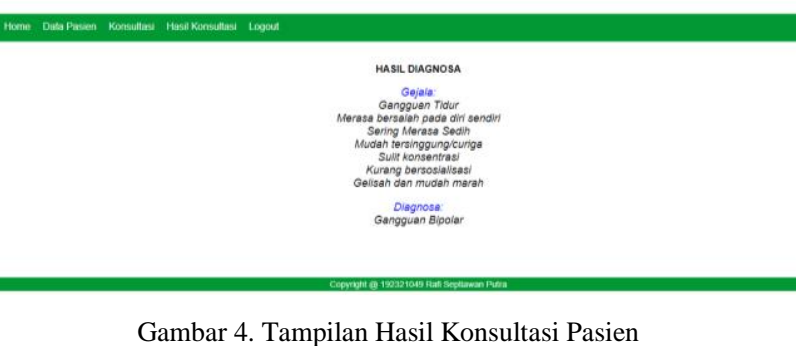

Gambar 4 menampilkan salah satu contoh data pasien yang menunjukan hasil analisis dari sistem pakar dalam menganalisis gangguan jiwa berdasarkan gejala-gejala gejala yang dialami.

\section{Kesimpulan}

Berdasarkan pengujian dan hasil yang dilakukan maka dapat diambil kesimpulan sebagai berikut: dengan adanya Sistem Pakar menggunakan metode Certainty Factor (CF) dalam menganalisis gangguan jiwa ini dapat mempermudah seseorang pasien atau keluarga pasien mengetahui apakah pasien mengalami gangguan jiwa atau tidak berdasarkan gejala-gejala yang terjadi sehari-hari serta dalam penerapan sistem pakar ini dapat mengetahui jenis gangguan jiwa yang dialami dapat menentukan pengambilan keputusan atau solusi dan beberapa terapi yang dapat di lakukan oleh masyarakat atau pasien itu sendiri.

\section{Daftar Rujukan}

[1] Sinaga, A.S.R. \& Simanjuntak, D., (2020). Sistem Pakar Deteksi Gizi Buruk Balita Dengan Metode Naïve Bayes Classifier. Jurnal Inkofar, http://dx.doi.org/10.46846/jurnalinkofar.v1i2.110.

[2] Setiabudi, W. U., Sugiharti, E., \& Arini, F. Y. (2017). Expert System Diagnosis Dental Disease Using Certainty Factor Method. Scientific Journal of Informatics, 4(1), 43-50. http://dx.doi.org/10.15294/sji.v4i1.8463.

[3] Sihotang, H. T., Panggabean, E., \& Zebua, H. (2019). Sistem Pakar Mendiagnosa Penyakit Herpes Zoster Dengan Menggunakan Metode Teorema Bayes. Journal Of Informatic Pelita Nusantara. 33-39 http://dx.doi.org/10.31227/osf.io/rjqgz 
[4] Purwasih, R., \& Wahyuni, S. (2019). sistem Pakar Sistem Pakar Penyakit Kuda Dengan Metoda Certainty Factor. Joisie (Journal Of Information Systems And Informatics Engineering), 3(2), 64. http://dx.doi.org/10.35145/joisie.v3i2.479

[5] Septyanto, A., \& Al Amin, I. (2020). Expert System for Diagnosing Newborn Babies Disease Using the Sorgenfrei Similarity Method. Journal of Applied Informatics and $\begin{array}{lll}\text { Computing } & \text { (JAIC), } & \text { 4(2), }\end{array}$ https://doi.org/10.30871/jaic.v4i2.2192

[6] Undang-Undang Republik Indonesia Nomor 18 Tahun 2014. Kesehatan Jiwa. 7 Agustus 2014. Lembaran Negara Republik Indonesia Tahun 2014 Nomor 5571. Jakarta. https://peraturan.go.id/common/dokumen/ln/2014/uu182014bt.pdf

[7] Nuryati, Kresnowati L. Klasifikasi dan Kodefikasi Penyakit dan Masalah Terkait III. Jakarta: Kementerian Kesehatan; 2018 http://bppsdmk.kemkes.go.id

[8] Supiandi, A., \& Chandradimuka, D. B. (2018). Sistem Pakar Diagnosa Depresi Mahasiswa Akhir Dengan Metode Certainty
Factor Berbasis Mobile. Jurnal Informatika, 5(1), 102-111. https://doi.org/10.31311/ji.v5i1.2872

[9] Putri, G. H. G. (2018). Sistem Pakar Diagnosa Mental Ilness Psikosis dengan Menggunakan Metode Certainty Factor. Jurnal $\begin{array}{lll}\text { Inovtek Polbeng. } & \text { 3(2), }\end{array}$ https://doi.org/10.35314/isi.v3i2.453

[10]Fahmi, H. (2019). Sistem Pakar Mendiagnosa Penyakit Mata Katarak Dengan Metode Certainty Factor Berbasis Web. MATICS, 11(1), 27. https://doi.org/10.18860/mat.v11i1.7673

[11]Suwarno, A., Husin, I., \& Zenni, U. E. (2019). Aplikasi Sistem Pakar Untuk Mendiagnosa Gangguan Kepribadian Pada Remaja Dengan Menggunakan Metode Certainty Factor (CF). KILAT, 8(2). https://doi.org/10.33322/kilat.v8i2.602

[12] Sudarmana, L. Lestari, F. (2018). Aplikasi Sistem Pakar Untuk mendiagnosis Gangguan Jiwa Schizophrenia. Jurnal Informatika: Jurnal Pengembangan IT (JPIT). 40-44. http://dx.doi.org/10.30591/jpit.v3i1.650 